\title{
The consequences of human-driven ocean acidification for marine life
}

\author{
Scott Doney
}

Address: Department of Marine Chemistry and Geochemistry, Woods Hole Oceanographic Institution, Woods Hole, MA 02549, USA

Email: sdoney@whoi.edu

Fl000 Biology Reports 2009, I:36 (doi:10.34I0/BI-36)

The electronic version of this article is the complete one and can be found at: http://FI000.com/Reports/Biology/content/I/36

\begin{abstract}
Rising atmospheric carbon dioxide is causing a wholesale shift in surface seawater chemistry, potentially threatening many marine organisms that form shells and skeletons from calcium carbonate. Recent papers suggest that the biological consequences of ocean acidification already may be underway and may be more complex, nuanced and widespread than previously thought.
\end{abstract}

\section{Introduction and context}

Present-day atmospheric carbon dioxide $\left(\mathrm{CO}_{2}\right)$ is almost $40 \%$ higher than pre-industrial levels due to human fossil-fuel combustion and deforestation, and atmospheric $\mathrm{CO}_{2}$ could reach double or triple historical levels by the end of this century. About a third of the excess $\mathrm{CO}_{2}$ released by humans enters the surface ocean where it acts to lower seawater $\mathrm{pH}$, carbonate ion $\left(\mathrm{CO}_{3}{ }^{2-}\right)$ concentration, and the saturation state of calcium carbonate $\left(\mathrm{CaCO}_{3}\right)$ minerals $[1,2]$. Several marine biological groups form shells or skeletons from calcium carbonate, including tropical and cold-water corals, mollusks, echinoderms, crustaceans, and some phytoplankton and zooplankton. In laboratory incubation studies, many of these calcifying organisms exhibit reduced calcification and other negative physiological effects at elevated $\mathrm{CO}_{2}$ levels comparable to what is expected over the next several decades, as reviewed recently in $[3,4]$ (Figure 1). Tropical coral reefs may be particularly sensitive to degradation from ocean acidification in conjunction with global warming, overfishing, pollution and habitat destruction [5]. Other marine ecosystems may experience acidification impacts through direct effects on susceptible populations, indirect food-web interactions, and alterations of biogeochemical cycling $[3,4]$.

\section{Major recent advances}

The research effort on ocean acidification is growing almost exponentially, resulting in a number of key recent advances. Anthropogenic changes in the carbonate chemistry of the surface ocean and the location of key marine fisheries and tropical corals are well prescribed, given projections of atmospheric $\mathrm{CO}_{2}$ and well-known thermodynamic relationships for seawater buffer capacity; globally, $\mathrm{pH}$ is estimated to have dropped by about $0.1 \mathrm{pH}$ units from the pre-industrial period to the present and a further decline of 0.3-0.4 $\mathrm{pH}$ units could occur by 2100 [4]. Ocean circulation and climate-change feedbacks, however, play a significant role in specific regions and when considering cold-water corals and subsurface ecosystems.

New studies suggest that ocean acidification may become a serious problem earlier than originally thought for some ocean regions. Coastal waters upwelling along the west coast of North America are already under-saturated for aragonite, a $\mathrm{CaCO}_{3}$ mineral used by corals and many mollusks [6], and corrosive conditions are predicted for the Southern Ocean [7] and Arctic [8] in one to a few decades. Coastal acidification also may be exacerbated by anthropogenic acid rain deposition [9]. 
Figure I. Representative examples of impacts of ocean acidification on major groups of marine organisms for experimental manipulation studies

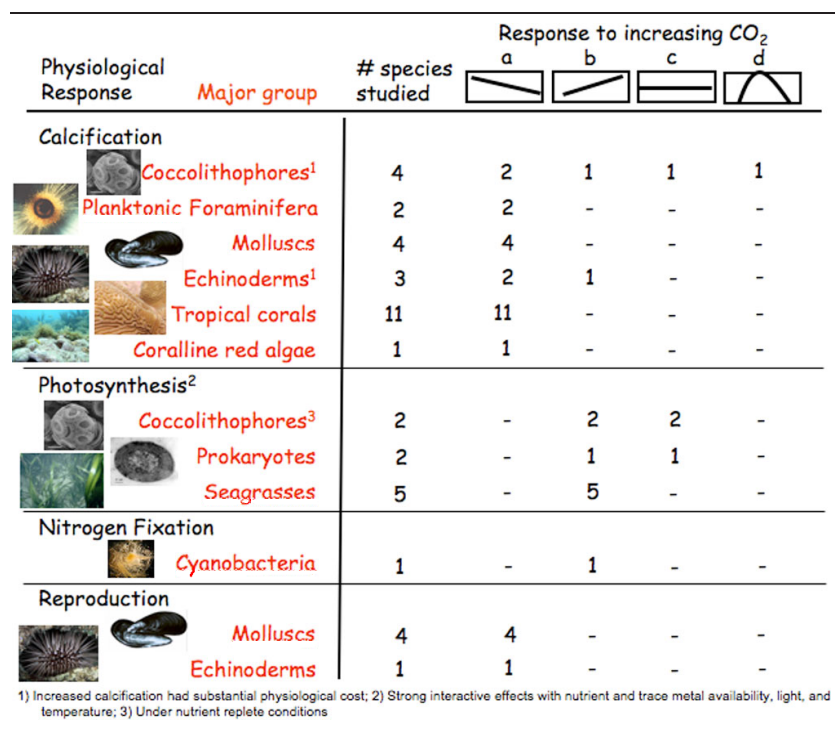

The response curves on the right indicate four cases: (a) linear negative, (b) linear positive, (c) level, and (d) non-linear parabolic responses to increasing levels of seawater partial pressure of $\mathrm{CO}_{2}$ for each of the groups. Adapted from [4].

Some of the early research on the biological impacts of acidification was motivated by the possibility of direct injection of $\mathrm{CO}_{2}$ into the ocean as a carbon sequestration strategy, and thus examined effects due to large $\mathrm{pH}$ perturbations $(\Delta \mathrm{pH}>1)$. A growing body of more recent laboratory incubation experiments involves more modest chemistry changes that are more representative of conditions expected to occur within this century. These studies confirm earlier findings showing reduced calcification with rising $\mathrm{CO}_{2}$ and a declining $\mathrm{CaCO}_{3}$ saturation state for tropical corals [10], mollusks [11], and crustose coralline algae (CCA) [12], an important reef builder.

The picture has become less clear for coccolithophores, a calcifying phytoplankton, with new studies suggesting substantial inter-species and strain variability. In fact, some experiments indicate increased cell-specific calcification and larger individual external calcite plates (coccoliths) at higher $\mathrm{CO}_{2}$ [13], the direct opposite of earlier work showing reduced calcification under acidification (reviewed in [3]). Records of changes in coccolith size over time from sediment cores also indicate an increase in coccolith size correlated with rising atmospheric $\mathrm{CO}_{2}$ for some species [13]. In contrast, sediment trap records of modern sinking planktonic foraminifera show a marked reduction in shell weights (30-35\%) relative to Holocene-aged sediments [14].

Tank experiments with tropical corals and CCA indicate synergistic effects between warming and elevated $\mathrm{CO}_{2}$, leading to enhanced sensitivity to bleaching [15]. Some calcifying higher organisms may be able to compensate for elevated $\mathrm{CO}_{2}$ but at a considerable metabolic cost [16]. In sea urchin larvae, elevated $\mathrm{CO}_{2}$ alters gene expression and may reduce tolerance to other environmental stresses [17]. Some photosynthetic organisms may benefit from future elevated aqueous $\mathrm{CO}_{2}$ and sea surface temperatures, as evident for Synechococcus, a common subtropical cyanobacteria [18]. Alleviation of $\mathrm{CO}_{2}$ limitation may enhance marine nitrogen fixation [19] and planktonic carbon to nitrogen elemental ratios, [20] thus altering ocean biogeochemistry.

Questions naturally arise as to the relevance of shortterm incubation and mesocosm experiments to field populations exposed to chronic, slowly increasing $\mathrm{CO}_{2}$ and other environmental trends [21]. Some caution is also warranted in interpreting laboratory experiments that use overly large amplitude chemistry changes (for example, $\Delta \mathrm{pH}$ of $1, \mathrm{CO}_{2}$ of 1,500-2,000 ppm). Many of the incubation results, however, are supported by work on historical time-series and marine environments with naturally elevated $\mathrm{CO}_{2}$. In a near-shore benthic community exposed to volcanic $\mathrm{CO}_{2}$ venting, corals, $\mathrm{CCA}$ and juvenile mollusks are absent and adult mollusks appear unhealthy, replaced by sea-grasses that experience $\mathrm{CO}_{2}$ limitation of photosynthesis at ambient levels [22]. Similar shifts in community composition were observed over time in a rocky inter-tidal pool exhibiting rapid $\mathrm{pH}$ reductions over a decadal time-scale [23].

The surface $\mathrm{CaCO}_{3}$ saturation state is low in the eastern tropical Pacific because of upwelling of $\mathrm{CO}_{2}$-rich water, resulting in poorly cemented coral reefs with enhanced bio-erosion rates [24]. Cores from several hundred massive Porites colonies on the Great Barrier Reef indicate a $14 \%$ reduction in calcification since 1990, an unprecedented event in at least the last 400 years that may reflect both warming and acidification [25]. Numerical model studies suggest that reefs may cease to grow or even show net dissolution when atmospheric $\mathrm{CO}_{2}$ reaches $560 \mathrm{ppm}$ [26], which could occur in the mid- to latter part of this century.

Novel studies are looking further afield for ocean acidification effects that have not yet been considered. For example, one study suggested that acidification and expanding oxygen-minimum zones could dramatically reduce the metabolic rates of giant squid [27]. Another 
study ties lower $\mathrm{pH}$ with decreased low-frequency sound absorption and a noisier undersea environment, which could in turn affect marine mammal communication [28]. Reduced seawater $\mathrm{pH}$ also appears to disrupt the olfactory sensory abilities of some larval fish [29]. More surprises surely await.

\section{Future directions}

Our present understanding of the biological consequences of ocean acidification is, to a large degree, empirical in nature, reflecting a limited understanding of the biological mechanisms of some key processes. There are open questions about the ocean calcium carbonate budget, as highlighted in a new study suggesting that the precipitation of carbonates within the intestines of marine fish may contribute as much as $3-15 \%$ to total ocean carbonate production [30]. Many details on $\mathrm{CaCO}_{3}$ biomineralization at the cellular level also remain to be resolved, with the potential for cross-fertilization with the material sciences research community [31].

Some of the most promising and challenging future directions will involve studying how changes in metabolic processes at the cellular level are manifested in terms of organism physiology and how this translates into altered population dynamics, community structure, and ecosystem function. Resolving the potential plasticity of species to acidification, which is dependent on existing diversity within and across populations, and micro-evolution and adaptation, is of particular importance [21]. Field manipulation techniques and mesocosms will develop in importance as a bridge between laboratory incubation experiments and cross-site comparisons with high $\mathrm{CO}_{2}$ environments.

Time-series measurements are needed to document the temporal evolution of susceptible target populations, such as pteropods and commercially valuable mollusks, and particularly sensitive ecosystems such as tropical and cold-water coral reefs. Methods development is underway on autonomous in situ chemical sensors for carbonate ion concentration measurement [32] and other components of the seawater carbonate system. Observational systems combining underway ship data and satellite data are emerging to monitor surface-ocean carbonate saturation state [33]. Similar development is required for biological processes. Satellite remote sensing algorithms can characterize the global patterns and rates of pelagic calcification over time [34].

Mitigation strategies for addressing ocean acidification have been proposed, including adding alkalinity to surface waters from limestone dust or accelerated weathering of volcanic rock [35], but the logistics, cost and energy demands are likely to be prohibitive, except on a small scale. In the end, the only true mitigation option will involve reducing $\mathrm{CO}_{2}$ emissions to the atmosphere. Given that some amount of further ocean acidification is inevitable over the next several decades, more applied work is needed to characterize socioeconomic impacts on coastal communities and to develop possible adaptation approaches for marine conservation and resource management [36].

\section{Abbreviations}

$\mathrm{CO}_{2}$, carbon dioxide; $\mathrm{CaCO}_{3}$, calcium carbonate; CCA, crustose coralline algae.

\section{Competing interests}

The author declares that he has no competing interests.

\section{References}

I. Feely RA, Sabine CL, Lee K, Berelson W, Kleypas J, Fabry VJ, Millero FJ: Impact of anthropogenic $\mathrm{CO}_{2}$ on the $\mathrm{CaCO}_{3}$ system in the oceans. Science 2004, 305:362-6.

FI000 Factor 3.0 Recommended

Evaluated by Scott Doney 22 Mar 2005

2. Orr JC, Fabry VJ, Aumont O, Bopp L, Doney SC, Feely RA Gnanadesikan A, Gruber N, Ishida A, Joos F, Key RM, Lindsay K, Maier-Reimer E, Matear R, Monfray P, Mouchet A, Najjar RG, Plattner G-K, Rodgers KB, Sabine CL, Sarmiento JL, Schlitzer R, Slater RD, Totterdell IJ, Weirig M-F, Yamanaka Y, Yool A: Anthropogenic ocean acidification over the twenty-first century and its impact on marine calcifying organisms. Nature 2005, 437:68I-6.

FI000 Factor 6.0 Must Read

Evaluated by Helen Yap 07 Oct 2005

3. Fabry VJ, Seibel BA, Feely RA, Orr JC: Impacts of ocean acidification on marine fauna and ecosystem processes. ICES J Mar Sci 2008, 65:4I4-32.

4. Doney SC, Fabry VJ, Feely RA, Kleypas JA: Ocean acidification: the other $\mathrm{CO}_{2}$ problem. Annu Rev Mar Sci 2009, I:I69-92.

5. Hoegh-Guldberg O, Mumby PJ, Hooten AJ, Steneck RS, Greenfield P, Gomez E, Harvell CD, Sale PF, Edwards AJ, Caldeira K, Knowlton N, Eakin CM, Iglesias-Prieto R, Muthiga N, Bradbury RH, Dubi A, Hatziolos ME: Coral reefs under rapid climate change and ocean acidification. Science 2007, 3 I 8: $1737-42$.

FI000 Factor 6.0 Must Read Evaluated by Russell Moll 08 Jan 2008

6. Feely RA, Sabine CL, Hernandez-Ayon JM, lanson D, Hales B: Evidence for upwelling of corrosive "acidified" water onto the continental shelf. Science 2008, 320:|490-2.

FI000 Factor 6.0 Must Read Evaluated by Scott Doney II Aug 2008

7. McNeil BI, Matear RJ: Southern Ocean acidification: A tipping point at 450-ppm atmospheric $\mathbf{C O}_{2}$. Proc Natl Acad Sci U S A 2008, 105: 18860-4.

8. Steinacher $M$, Joos $F$, Frölicher $T$, Plattner G-K, Doney SC: Imminent ocean acidification projected with the NCAR global coupled carbon cycle-climate model. Biogeosciences 2009, 6:515-33.

9. Doney SC, Mahowald N, Lima I, Feely RA, Mackenzie FT, Lamarque J-F, Rasch PJ: The impact of anthropogenic atmospheric nitrogen and sulfur deposition on ocean acidification 
and the inorganic carbon system. Proc Natl Acad Sci U S A 2007, 104: | 4580-5.

10. Langdon C, Atkinson MJ: Effect of elevated $\mathrm{pCO}_{2}$ on photosynthesis and calcification of corals and interactions with seasonal change in temperature/irradiance and nutrient enrichment. J Geophys Res Oceans 2005, II 0:C09S7.

II. Gazeau F, Quiblier C, Jansen JM, Gattuso JP, Middelburg JJ, Heip CHR: Impact of elevated $\mathrm{CO}_{2}$ on shellfish calcification. Geophys Res Lett 2007, 34:L07603.

FI000 Factor 6.4 Must Read

Evaluated by Rik Leemans 9 May 2007, John Marra I3 Jun 2007

12. Kuffner IB, Andersson AJ, Jokiel PL, Rodgers KS, Mackenzie FT: Decreased abundance of crustose coralline algae due to ocean acidification. Nat Geosci 2008, I: I 14-7.

FI000 Factor 3.0 Recommended

Evaluated by Scott Doney 9 Jan 2008

13. Iglesias-Rodriguez MD, Halloran PR, Rickaby REM, Hall IR, Colmenero-Hidalgo E, Gittins JR, Green DRH, Tyrrell T, Gibbs SJ, von Dassow P, Rehm E, Armbrust EV, Boessenkool KP: Phytoplankton calcification in a high- $\mathrm{CO}_{2}$ world. Science 2008, 320:336-40.

FI000 Factor 6.4 Must Read

Evaluated by Scott Doney 22 Apr 2008, Anand Gnanadesikan 22 Apr 2008

14. Moy AD, Howard WR, Bray SG, Trull TW: Reduced calcification in modern Southern Ocean planktonic foraminifera. Nat Geosci 2009, 2:276-80.

FI000 Factor 6.0 Must Read

Evaluated by Anand Gnanadesikan 24 Mar 2009

15. Anthony KRN, Kline DI, Diaz-Pulido G, Dove S, Hoegh-Guldberg O: Ocean acidification causes bleaching and productivity loss in coral reef builders. Proc Natl Acad Sci U S A 2008, 105: 17442-6.

FI000 Factor 6.0 Must Read

Evaluated by Helen Yap 23 Jan 2009

16. Wood HL, Spicer JI, Widdicombe S: Ocean acidification may increase calcification rates, but at a cost. Proc Royal Soc B Bio Sci 2008, 275: 1767-73.

FI000 Factor 3.0 Recommended

Evaluated by Scott Doney II Aug 2008

17. O'Donnell M, Hammond L, Hofmann G: Predicted impact of ocean acidification on a marine invertebrate: elevated $\mathrm{CO}_{2}$ alters response to thermal stress in sea urchin larvae. Mar Biol 2009, I 56:439-46.

FI000 Factor 3.0 Recommended

Evaluated by John Pandolfi 9 Feb 2009

18. Fu F-X, Warner ME, Zhang Y, Feng Y, Hutchins DA: Effects of increased temperature and $\mathrm{CO}_{2}$ on photosynthesis, growth and elemental ratios of marine Synechococcus and Prochlorococcus (cyanobacteria). J Phycol 2007, 43:485-96.

19. Levitan O, Rosenberg G, Setlik I, Setlikova E, Grigel J, Klepetar J, Prasil $\mathrm{O}$, Berman-Frank I: Elevated $\mathrm{CO}_{2}$ enhances nitrogen fixation and growth in the marine cyanobacterium Trichodesmium. Global Change Biol 2007, I3:53I-8.

20. Riebesell $U$, Schulz KG, Bellerby RG], Botros M, Fritsche $P$, Meyerhöfer M, Neill C, Nondal G, Oschlies A, Wohlers J, Zöllner E: Enhanced biological carbon consumption in a high $\mathrm{CO}_{2}$ ocean. Nature 2007, 450:545-8.

FI000 Factor 4.9 Must Read

Evaluated by Robert Sterner 26 Nov 2007, John Marra 03 Jan 2008, Daniel Vaulot I2 Dec 2007
21. Boyd PW, Doney SC, Strzepek R, Dusenberry J, Lindsay K, Fung I: Climate-mediated changes to mixed-layer properties in the Southern Ocean: assessing the phytoplankton response. Biogeosciences 2008, 5:847-64.

22. Hall-Spencer JM, Rodolfo-Metalpa R, Martin S, Ransome E, Fine M, Turner SM, Rowley SJ, Tedesco D, Buia MC: Volcanic carbon dioxide vents show ecosystem effects of ocean acidification. Nature 2008, 454:96-9.

FI000 Factor 6.7 Must Read

Evaluated by Robert Paine 17 Jul 2008, Edward Laws 18 Jul 2008, Richard Frankham 0 I Aug 2008, Robie Macdonald 20 Jan 2009

23. Wootton JT, Pfister CA, Forester JD: Dynamic patterns and ecological impacts of declining ocean $\mathrm{pH}$ in a high-resolution multi-year dataset. Proc Natl Acad Sci U S A 2008, 105:18848-53.

FI000 Factor 8.I Exceptional

Evaluated by John Pandolfi 10 Dec 2008, Simon Thrush II Dec 2008, Jonathan Chase 19 Dec 2008

24. Manzello DP, Kleypas JA, Budd DA, Eakin CM, Glynn PW, Langdon C: Poorly cemented coral reefs of the eastern tropical Pacific: Possible insights into reef development in a high- $\mathrm{CO}_{2}$ world. Proc Natl Acad Sci U S A 2008, 105:10450-5.

25. De'ath G, Lough JM, Fabricius KE: Declining coral calcification on the Great Barrier Reef. Science 2009, 323: I 16-9.

FI000 Factor 6.0 Must Read

Evaluated by Andrew Baird 21 Jan 2009

26. Silverman J, Lazur B, Cao L, Caldeira K, Erez J: Coral reefs may start dissolving when atmospheric $\mathrm{CO}_{2}$ doubles. Geophys Res Lett 2009, 36:L05606.

27. Rosa R, Seibel BA: Synergistic effects of climate-related variables suggest future physiological impairment in a top oceanic predator. Proc Natl Acad Sci U S A 2007, 105:20776-80.

28. Hester KC, Peltzer ET, Kirkwood WJ, Brewer PG: Unanticipated consequences of ocean acidification: A noisier ocean at lower pH. Geophys Res Lett 2008, 35:LI960I.

29. Munday PL, Dixson DL, Donelson JM, Jones GP, Pratchett MS Devitsina GV, Døving KB: Ocean acidification impairs olfactory discrimination and homing ability of a marine fish. Proc Nat Acad Sci U S A 2009, 106:1848-52.

30. Wilson RW, Millero FJ, Taylor JR, Walsh PJ, Christensen V, Jennings S, Grosell M: Contribution of fish to the marine inorganic carbon cycle. Science 2009, 323:359-62.

FI000 Factor 3.0 Recommended

Evaluated by Boris Worm 02 Feb 2009

3I. Pouget EM, Bomans PH, Goos JA, Frederik PM, de With G Sommerdijk NA: The initial stages of template-controlled $\mathrm{CaCO}_{3}$ formation revealed by cryo-TEM. Science 2009, 323: 1 455-8.

32. Byrne RH, Yao WS: Procedures for measurement of carbonate ion concentrations in seawater by direct spectrophotometric observations of $\mathrm{Pb}$ (II) complexation. Mar Chem 2008, I I 2: 128-35.

33. Gledhill DK, Wanninkhof R, Millero FJ, Eakin M: Ocean acidification of the Greater Caribbean Region 1996-2006. J Geophys Res Oceans 2008, II3:CI003I.

34. Balch W, Drapeau D, Bowler B, Booth E: Prediction of pelagic calcification rates using satellite measurements. Deep Sea Res II 2007, 54:478-95

35. House KZ, House CH, Schrag DP, Aziz MJ: Electrochemical acceleration of chemical weathering as an energetically feasible approach to mitigating anthropogenic climate change. Env Sci Tech 2007, 41:8464-70.

36. Cooley SR, Doney SC: Ocean acidification's impact on fisheries and societies: a U.S. perspective. Curr J Mar Educ 2009, 25: 15-19. 